\begin{tabular}{|l|l|}
\hline 2. To: (Receiving Organization) & 3. From: (Originating Organization) \\
Materials \& Special & Civil/Structural/Env. \\
Projects, & Engineering, Fluor Daniel \\
Babcock \& Wilcox Hanford Co. & Northwest, Inc. \\
\hline 5. Proj./Prog./Dept./Div.: & $\begin{array}{l}\text { Design Authority/ Design Agent/Cog. } \\
\text { Engr.: }\end{array}$ \\
Canyon Disposition & J. E. Rugg/J. T. \\
Initiative & Baxter/George Cox \\
\hline
\end{tabular}

8. Originator Remarks:
4. Related EDT No.:

$N / A$

7. Purchase Order No.:

Task Order 65100201 A21

9. Equip./Component No.: N/A

10. Systen/Bldg./Facility: Building 221-U

11. Receiver Remarks: 11A. Design Baseline Document? [X] Yes [] No
12. Major Assm. Dwg. No.: Specification \#1817

13. Permit/Permit Application No.: $N / A$

14. Required Response Date: $N / A$

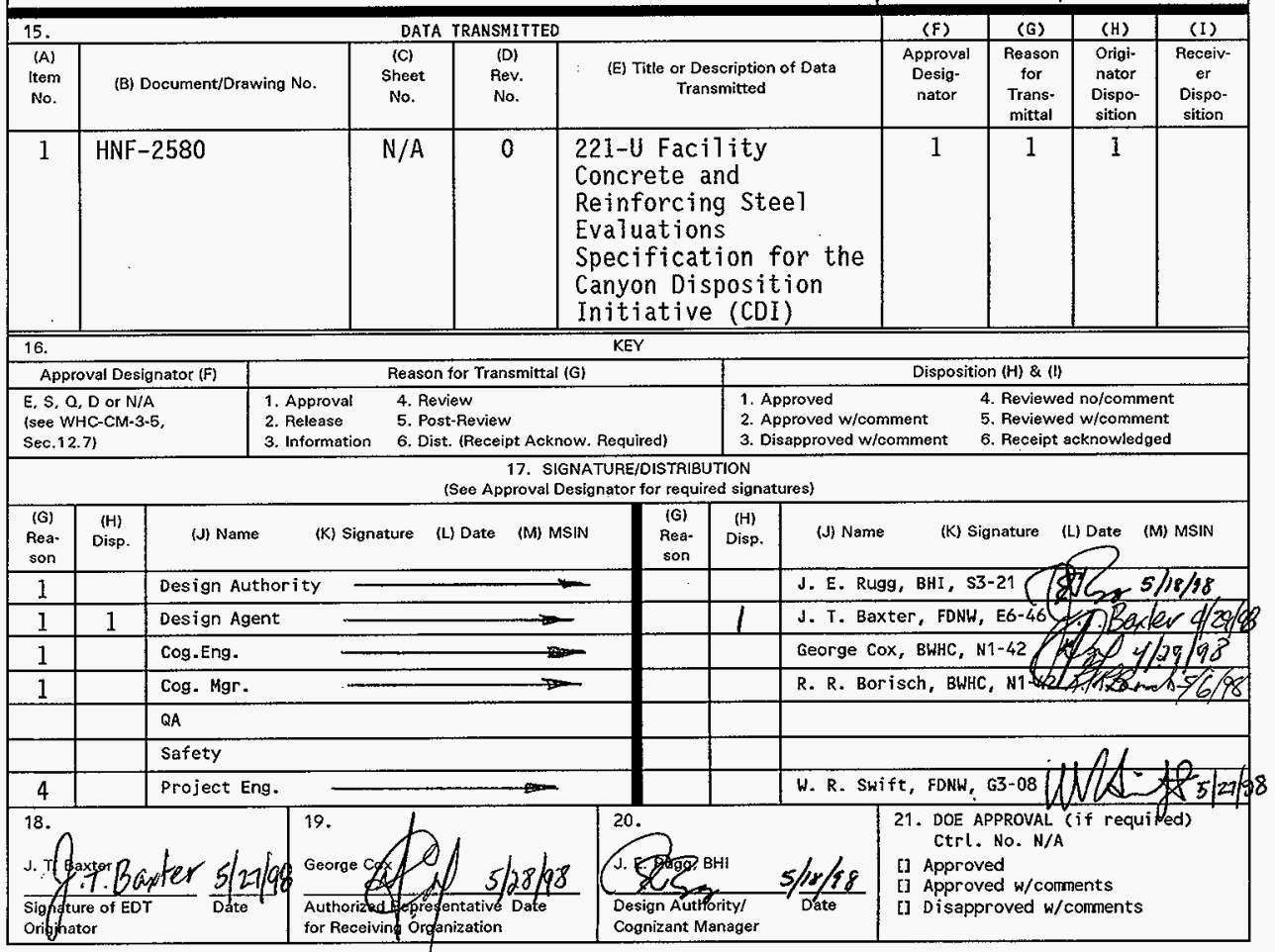

BD-7400-172-2 (05/96) GEF097 


\section{1-U FACILITY CONCRETE AND REINFORCING STEEL EVALUATIONS SPECIFICATION FOR THE CANYON DISPOSITION INITIATIVE (CDI)}

J. T. Baxter,

Fluor Daniel Northwest, Inc.

Richland, WA 99352

U.S. Department of Energy Contract DE-AC06-96RL13200

$\begin{array}{llll}\text { EDT/ECN: } & 623847 & \text { UC: UC-2050 } & \\ \text { Org Code: } & \text { ED300000 } & \text { Charge Code: K1C2A, } 65100201 \text { A21 } \\ \text { B\&R Code: } & \text { EW7002010 } & \text { Total Pages: } 2 Z 23 \\ & & \end{array}$

Key Words: design verification, in-situ materials properties, concrete and reinforcing steel evaluations, Building 221-U, canyon disposition initiative

Abstract: Test program to establish the in-situ material properties of the reinforced concrete in Building 221-U for comparison to the original design specifications. Field sampling and laboratory testing of concrete and reinforcing steel structural materials in Building 221-U for design verification. Forty seven samples are to be taken from radiologically clean exterior walls of the canyon. Laboratory testing program includes unconfined compressive strength of concrete cores, tensile strength of reinforcing steel, and petrographic examinations of concrete cores taken from walls below existing grade.

TRADEMARK DISCLAIMER. Reference herein to any specific comercial product, process, or service by trade name, trademark, manufacturer, or otherwise, does not necessarily constitute or imply its endorsement, recommendation, or favoring by the United States Government or any agency thereof or its contractors or subcontractors.

Printed in the United States of America. To obtain copies of this document, contact: Document Control Services, P.0. Box 950, Mailstop H6-08, Richland WA 99352, Phone (509) 372-2420; Fax (509) $376-4989$.
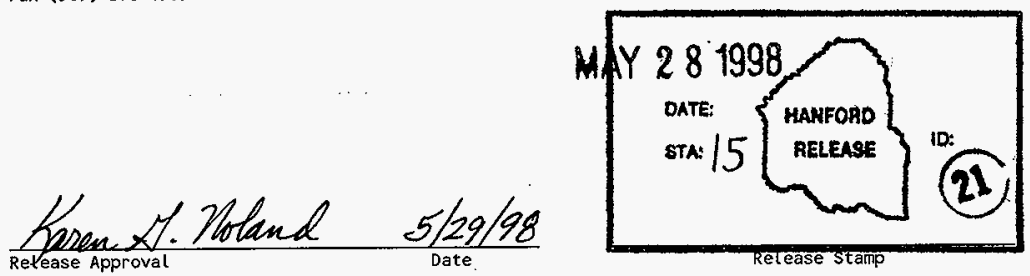


\section{CANYON DISPOSITION INITIATIVE (CDI)}

\section{TECHNICAL SPECIFICATION}

\section{FOR CONCRETE AND REINFORCING STEEL EVALUATIONS \\ OF THE 221-U FACILITY}

Revision 0

April 27, 1998 
TABLE OF CONTENTS

Page No.

1.0 BACKGROUND AND SCOPE . 3

2.0 GENERAL STRATEGY AND CONSIDERATIONS 3

3.0 SAMPLE LOCATIONS AND DESCRIPTIONS 4

3.1 Work Sequence 4

3.2. Above Grade Nondestructive Examination (NDE) 6

3.3 Above Grade Structural Sampling 6

3.4 Excavation 9

3.5 Below Grade Nondestructive Examination (NDE) 9

3.6 Below Grade Structural Sampling 9

3.7 Sample Numbering 9

3.8 Worksheets for Structural Sampling 12

FIGURES

Figure 3-1 Typical Sidewall Sample Locations 7

Figure 3-2 East End Wall (U-Plant Segment I) Core Sampling Locations $\quad 8$

Figure 3-3 Excavation Location -- Plan View of West End of Building 221-U 10

Figure 3-4 Below Grade Structural Sampling Locations 11

TABLES

Table 1. Technical Specification for Structural Sampling of Building 221-U

\section{APPENDICES}

Appendix A. Petrographic Analysis Statement of Work 


\subsection{BACKGROUND AND SCOPE}

This technical specification establishes the requirements for concrete and reinforcing steel (rebar) sampling and testing to support structural evaluations of the 221-U Facility as defined in the Sampling and Analysis Plan (SAP) for 221-U Facility (DOE/RL-97-68, Revision 0). This specification will be used to assist in the preparation of work instructions and subcontract documents that implement the structural evaluation.

The general scope for this specification is as follows: A non-destructive examination (NDE) is specified to locate the reinforcing steel on selected portions of the outside walls of the facility. A total of 47 samples described in Section 3 comprise the scope of the test program. Sampling locations and specifications for both concrete coring and rebar removal are identified. Instructions are included for ancillary activities such as above-grade sampling, below-grade excavation and patching of holes associated with the structural sampling. Requirements are also established for laboratory testing activities such as sample characterization, sample preparation, concrete compressive strength testing, rebar tensile strength testing, petrographic examinations, data analysis and reporting of test results.

Readers are referred to the Sampling and Analysis Plan for 221-U Facility for general background information on, and past operations in the 221-U Facility.

\subsection{GENERAL STRATEGY AND CONSTDERATIONS}

Section 1.5 .9 of the SAP describes the general sampling strategy intended to determine the as-built strength of U-Plant materials. This technical specification fulfills the intent of, and supersedes the SAP by detailing scope and requirements that take into account new technical information acquired subsequent to the issuance of the SAP. The general strategy can be summarized as follows:

Concrete compressive strength test samples shall be cored from: a) accessible, radiologically clean, outside-wall locations on the gallery side of the U-Plant; and b) the North end-wall of U-Plant. In addition the SAP specifies that rebar samples are to be taken in locations proximate to each of these new coring locations because the facility strength deperids primarily on the rebar condition, location and strength. The SAP calls for the use of NDE methods to assess rebar locations for comparison to the drawings at most locations in addition to obtaining rebar samples. The end wall is unreinforced and therefore, end-wall concrete samples do not contain rebar.

The SAP sampling and testing effort calls for taking into account the variability in the original construction materials used to build the 221-U Building. Therefore, samples are to be taken from locations close to Segments 5 and 20 which contain the oldest and youngest (respectively) concrete and rebar. In this specification, Segment 4 was chosen instead of Segment 5 because the latter is currently contaminated. As noted in the SAP, radiologically clean accessible locations are the preferred locations for sampling. 221-U plant operators were contacted to discuss selection of clean locations on the outside of the canyon. Excavation is to be limited to areas free of known underground contamination. 
HNF-2580 Revision 0

Reinforcing steel sample locations were selected to preclude sampling in highiy stressed areas of the 221U structure and limit reductions on structural member strengths at the selected sample locations.

Therefore, this specification limits the number of rebar samples to one sample for each above-grade sidewall concrete coring location (instead of three samples each as discussed in the SAP. Additional NDE to verify rebar locations is called for in this specification for analytical compensation of the planned reduction in the number of rebar samples. The reduced rebar sample population will adequately fulfill information needs for planned structural evaluations.

Concrete coring requires the use of a small flow of water to cool the coring bit and carry the cuttings out of the core hole. The water is injected on the inside face of the coring barrel, travels to the cutting edge, and then flows back out to the concrete face on the outside of the coring barrel. Although concrete core and rebar acquisition is to be conducted only on the outside surfaces of the building, a highly unlikely possibility exists for small water flows to migrate to the inside of the building. This should be considered along with the standard safety-related evaluations associated with approvals to start work.

\subsection{SAMPLE LOCATIONS AND DESCRIPTIONS}

A total of 47 samples shall be taken from designated locations on the outside walls of building $221-\mathrm{U}$ as follows. (For details, see Table 1, located at the end of this Specification.)

- Twelve (12) concrete core samples shall be taken for strength testing of the above-grade sidewalls. Four (4) each from U Plant segments 20, 16 and 4.

- Two (2) concrete core samples are to be taken above grade at segment 20 to provide control samples for petrography.

- Twelve (12) rebar samples shall be taken, 1 each adjacent to the location for each above-grade core sample. These samples are for strength testing.

- Nine (9) concrete core samples shall be taken for strength testing of the unreinforced concrete end wall of U Plant segment 1. Three (3) core samples from 3 separate locations on the end wall.

- Twelve (12) concrete core samples taken at selected locations on the below-grade sidewall concrete at U Plant segment 20. Six (6) of these samples are for strength testing. The remaining 6 are to be used for petrographic examinations.

Sampling locations and supplementary requirements are described in the following sections.

\subsection{Work Sequence}

A suggested mobilization sequence for performing the work at $221-U$ facility is described in this section. Sampling activities are expected to be performed by a qualified subcontractor under the direction of Fluor Daniel Northwest (FDNW) and Babcock \& Wilcox Hanford Company (BWHC), with field support from 
HINF-2580 Revision 0

Bechtel Hanford Inc. (BHI) in the form of personnel, equipment and site preparation. The final work sequence shall be established via approved field work instructions. Non-destructive examinations to identify rebar locations shall be conducted prior to initiating coring work. Patching of core-bore holes may be done in a sequence that best accommodates the overall job. See Table 1 (located at the end of this Specification) for industry standards that will govern the sampling activities.

1. Above Grade NDE

Mobilize the NDE contractor to locate rebar in the walls above grade at segments 20,16 and 4 . Cognizant personnel from BWHC/FDNW will select sample locations at this time. Conduct NDE examinations approximately $5 \mathrm{ft}$ below the roofline to locate rebar in the roof walls of segments 20,16 and 4 over the full width of the segments $(\sim 40 \mathrm{ft})$. Elevated NDE work will require use of a manlift and qualified operator furnished by Fluor Daniel Northwest, Inc. (FDNW) construction forces.

2. Above Grade Structural Sampling Mobilize the sampling contractor to core concrete samples and excavate rebar samples from selected locations above grade on Building 221-U walls at segments 20,16 and 4 . Core concrete samples from the end wall of segment 20 above grade. Elevated coring work will require use of a manlift and qualified operator furnished by FDNW construction forces.

3. Excavation at Segment 20

Bechtel Hanford, Inc. (BHI) shall perform excavation at Building 221-U segment 20 to expose the building sidewall from the existing grade down to a depth of $\sim 10 \mathrm{ft}$. Radiation monitoring will be required during excavation.

\section{Below Grade NDE}

Mobilize the NDE contractor to locate rebar on the below grade wall face of segment 20. Cognizant personnel from BWHC/FDNW will select sample locations at this time.

5. Below Grade Structural Sampling

Mobilize the sampling contractor to core concrete samples from the below grade face of the wall of segment 20.

6. Backfill of Excavated Site

BHI shall backfill the excavation at segment 20 and restore the surface installations as required.

7. Sample Release

Each structural sample shall be surveyed for radiological contamination and approved for release outside Hanford. Structural samples shall be identified and inventoried. The subcontractor responsible for concrete coring shall provide packaging and shipping services for shipment of samples to the laboratories. 
HNF-2580 Revision 0

\subsection{Above Grade Nondestructive Examination (NDE)}

The NDE subcontractor shall locate rebar and mark the lower walls of segments 20,16 and 4 for rebar locations. Specific vertical and horizontal rebar sample locations in the sidewalls will be selected by cognizant FDNW/ BWHC personnel prior to sampling. Note that existing electrical equipment installations limit the available width of canyon wall for structural samples near grade to about $25 \mathrm{ft}$ as shown in Figure 3-1.

The upper outside walls of canyon segments 20,16 and 4 shall be scanned using NDE equipment to locate the main strength vertical rebar of the roof system for comparison to existing "as-built" drawings for building 221-U. Reinforcement bars of interest are bars 1001 and 1002 shown on drawing W69566 and detailed on drawing W69333. Based on the drawings, these bars are 1-1/4 square with 2 in cover. The reinforced concrete roof structure is a rigid frame which spans the canyon from one crane rail wall to the other. These bars are the main negative moment reinforcement where the roof beam intersects the short sidewall columns of the rigid frame. Location scanning shall be conducted at a distance of about 5 ft. below the edge of the building roof over the entire width of the canyon segment. The location of each vertical main strength bar shall be marked where detected. One row of horizontal rebar shall be scanned and marked above and below the row of vertical bars (scan area is approximately $2 \mathrm{ft}$ high by $40 \mathrm{ft}$ long). Marks for vertical rebar shall be a minimum of 1 inch in width, with a length of at least 12 inches.

\subsection{Above Grade Structural Sampling}

Four concrete cores and rebar samples shall be taken from the north side of the canyon a few feet above grade in the outside walls of segments 4, 16 and 20 as shown in Figure 3-1. Two additional concrete cores shall be taken from the sample area on the wall of segment 20 to be used for petrographic examination control samples. See Table 1, Section A for additional information on required above grade structural sampling.

Structural sampling includes concrete core sampling of one of the unreinforced concrete canyon end walls. Barriers are erected around the east end wall (segment 1 ) because of potential subsurface contamination; however, reasonable access is possible for coring operations. Three sets of (3) concrete cores shall be taken. Locations for these samples are shown in Figure 3-2. One set of samples shall be taken from the outside face of the unreinforced concrete end wall of the piping or electrical gallery. The second and third set of samples shall be taken from the $5 \mathrm{ft}$ thick and $3 \mathrm{ft}$ thick unreinforced concrete end walls that close the canyon space above the process cells.

Holes associated with the concrete coring and rebar sampling program shall be patched during, or immediately after above grade structural sampling has been completed. Grout used for concrete repairs shall obtain a minimum strength of 4000 psi at 28 days after placement. 


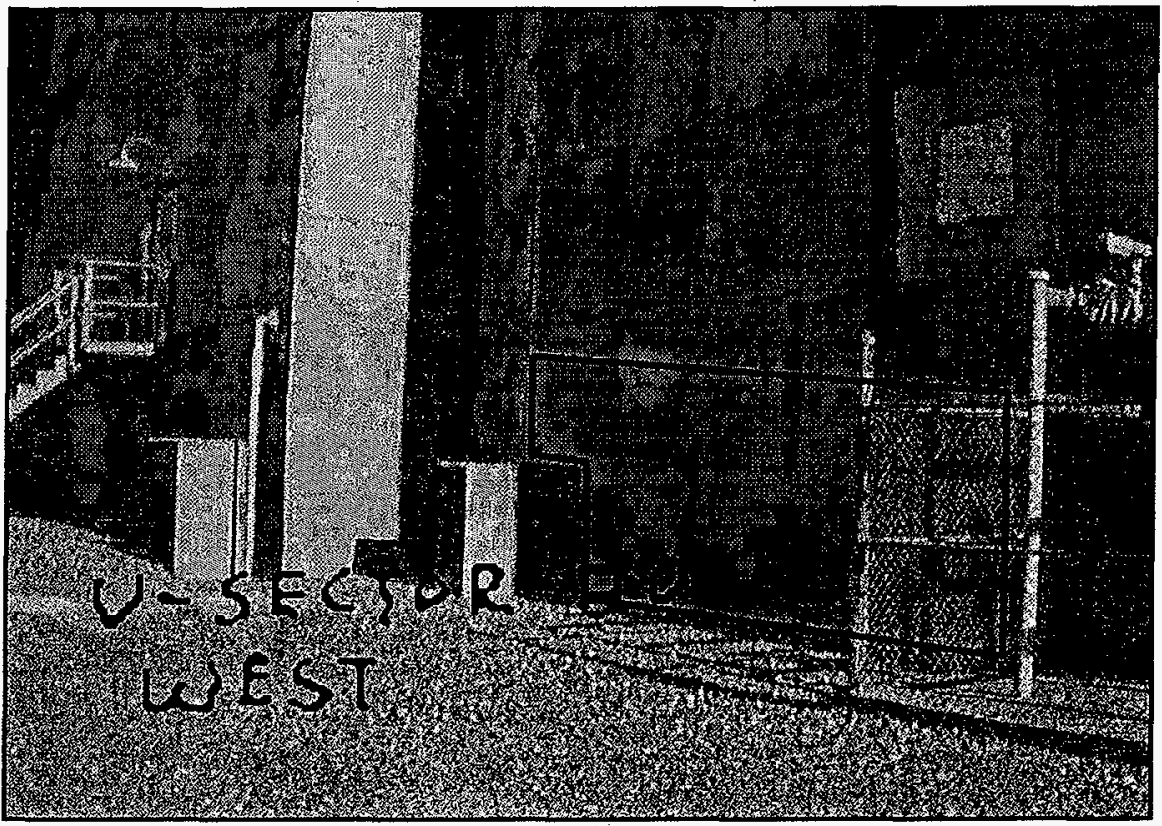

Figure 3-1. Typical Sidewall Sample Locations.

Notes on Figure 3-1

1. Specific sampling locations will be marked on the wall upon completion of nondestructive examination used to locate rebar.

2. Concrete cores and rebar samples are to be taken from the sidewall area of segment 20 outlined on the figure. Sampling areas at segments 16 and 4 are similar. This area extends from the joint on the left, between this segment and the next segment, to the edge of the chain link cage around the electrical equipment.

3. Concrete core samples and rebar samples are to be separated laterally by not less than $4 \mathrm{ft}-6$ in. An edge distance of not less than $3 \mathrm{ft}-0$ in shall be provided from the edge of the segment to the edge of the first core sample or slot for excavation of the first vertical rebar. Two additional cores shall be taken from segment 20 . These cores shall be located $2 \mathrm{ft}$ above the first row of 4 core samples. 
HNF-2580 Revision 0

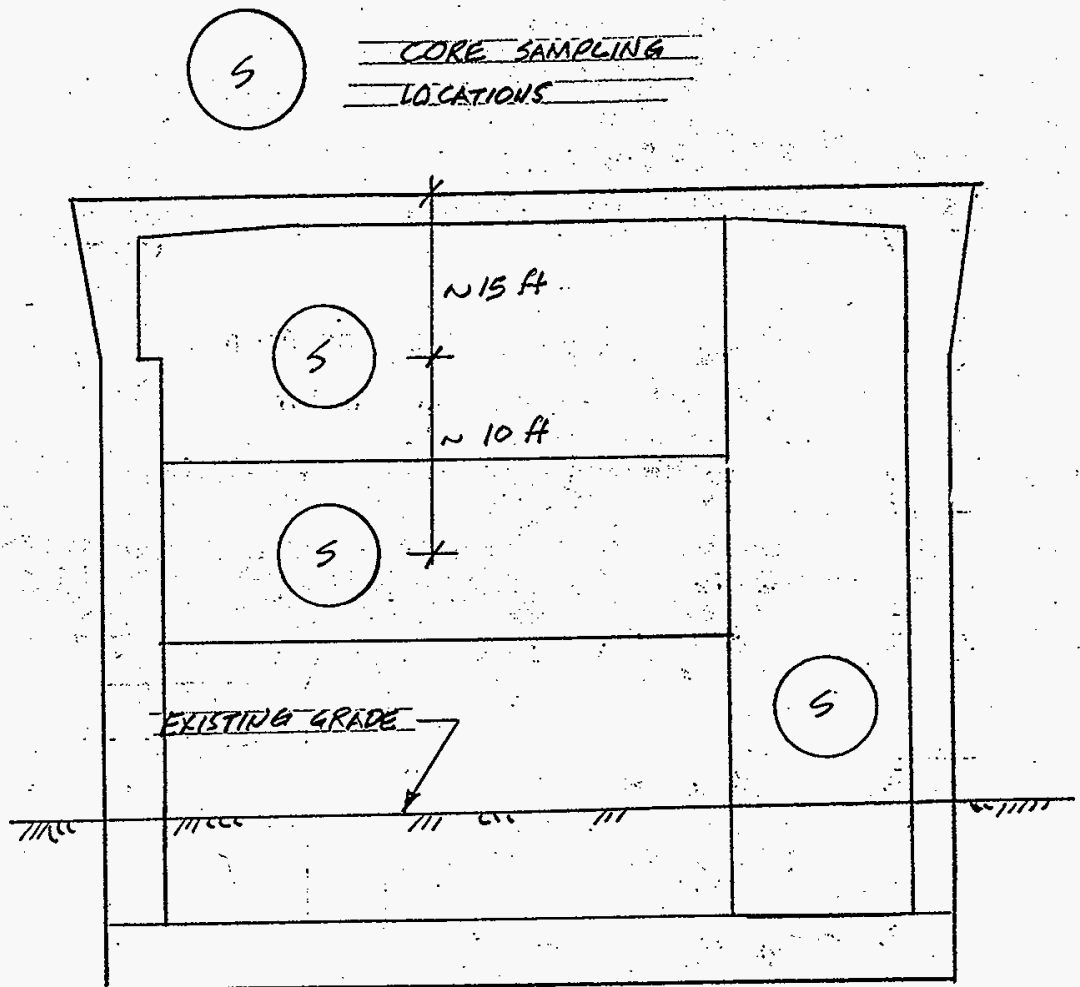

Figure 3-2. East End Wall (U-Plant Segment 1) Core Sampling Locations 


\subsection{Excavation}

Bechtel Hanford, Inc. (BHI) shall perform excavation at Building 221-U segment 20 to expose the building sidewall from the existing grade down to $\sim 10 \mathrm{ft}$. The plan location of this excavation is shown in Figure 3-3. Side slopes on the excavation shall be no steeper than $1-1 / 2$ horizontal to 1 vertical to assure personnel safety. Assuming a maximum slope of 1.5:1 horizontal to vertical on the sides of the excavation, the excavation will extend out to the sidewalk in front of the parking area. After excavation, the below grade wall of 221-U shall be broom cleaned and hosed down to remove loose soil in order to facilitate visual inspection.

\subsection{Below Grade Nondestructive Examination (NDE)}

Cognizant personnel from FDNW or BWHC shall conduct a visual inspection of the below grade wall to identify appropriate sample locations prior to NDE for rebar location. The NDE subcontractor shall locate rebar and mark the below grade wall of Segment 20 for rebar locations and sample locations for concrete cores. Vertical and horizontal rebar locations in the sidewall below grade shall be marked prior to sampling. The sampling pattern for the lower sidewall may be similar to that shown in Figure 3-4.

\subsection{Below Grade Structural Sampling}

Twelve concrete core samples shall be taken from the below grade wall of segment 20 at marked locations. Six of these samples shall be used for strength testing (unconfined compression tests), while the other six core samples will be used for petrographic analysis. See Table 1, Section B for additional information on required below grade structural sampling.

Holes associated with the concrete coring program shall be patched during, or immediately after below grade structural sampling has been completed. Grout used for concrete repairs shall obtain a minimum strength of $4000 \mathrm{psi}$ at 28 days after placement.

\subsection{Sample Numbering}

Concrete core and rebar samples shall be identified using a numbering system based on the segment number where the samples are taken, an indicator for the type of sample, and sequential numbering for the each type sample in a given segment. For example; sample i.d. $20-\mathrm{C}-001$, would be the first concrete core sample from segment 20 . Nomenclature will be:

$\begin{array}{clc}\text { Segment No. } & \text { Sample Type } & \text { Sequential No. } \\ 1-20 & \mathbf{C} \text { - concrete } & 0-12 \\ & \mathbf{R}-\text { rebar } & \\ & \mathbf{U} \text { - below grade } & \end{array}$




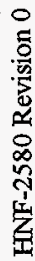

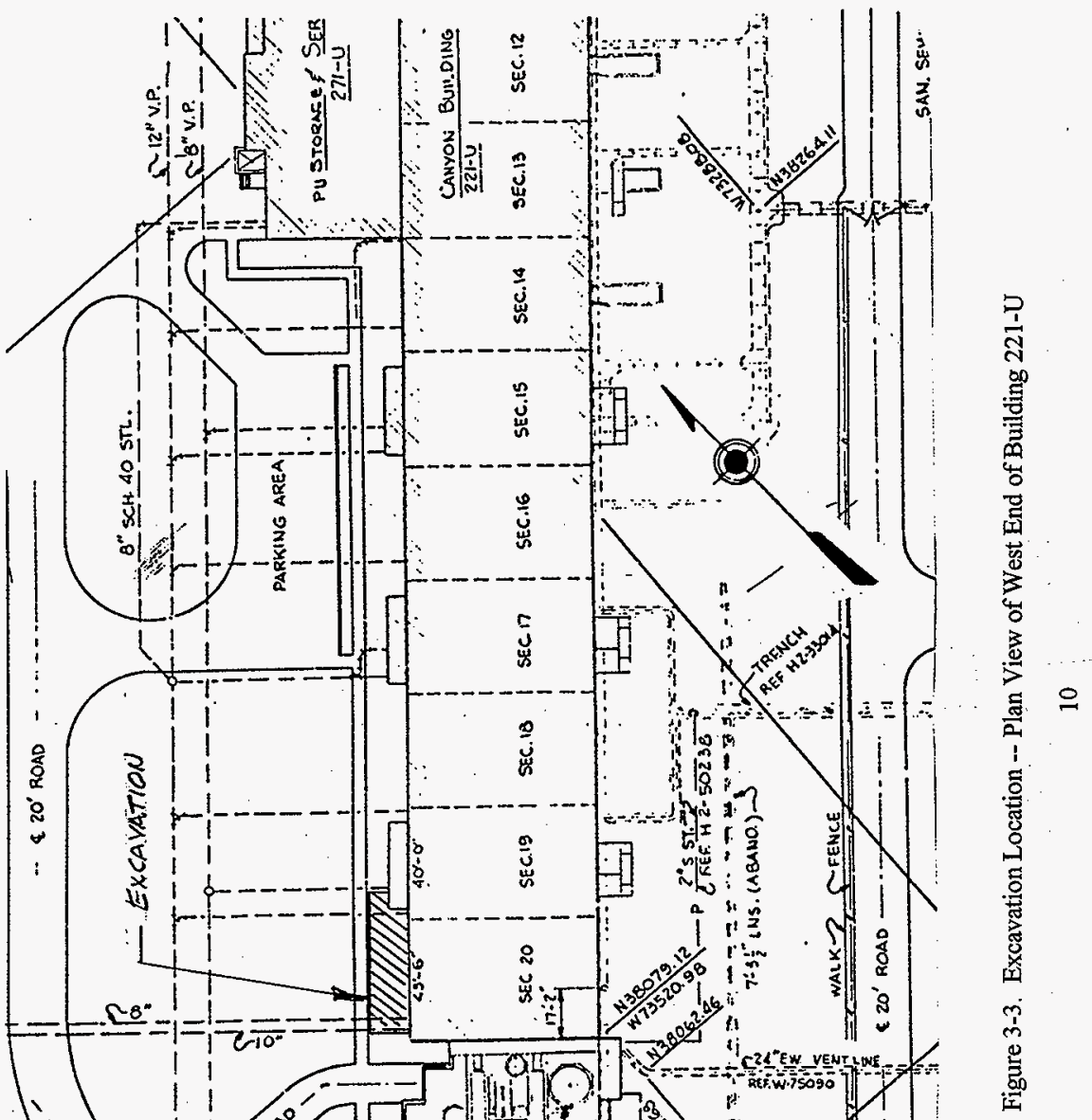


HNF-2580 Revision 0

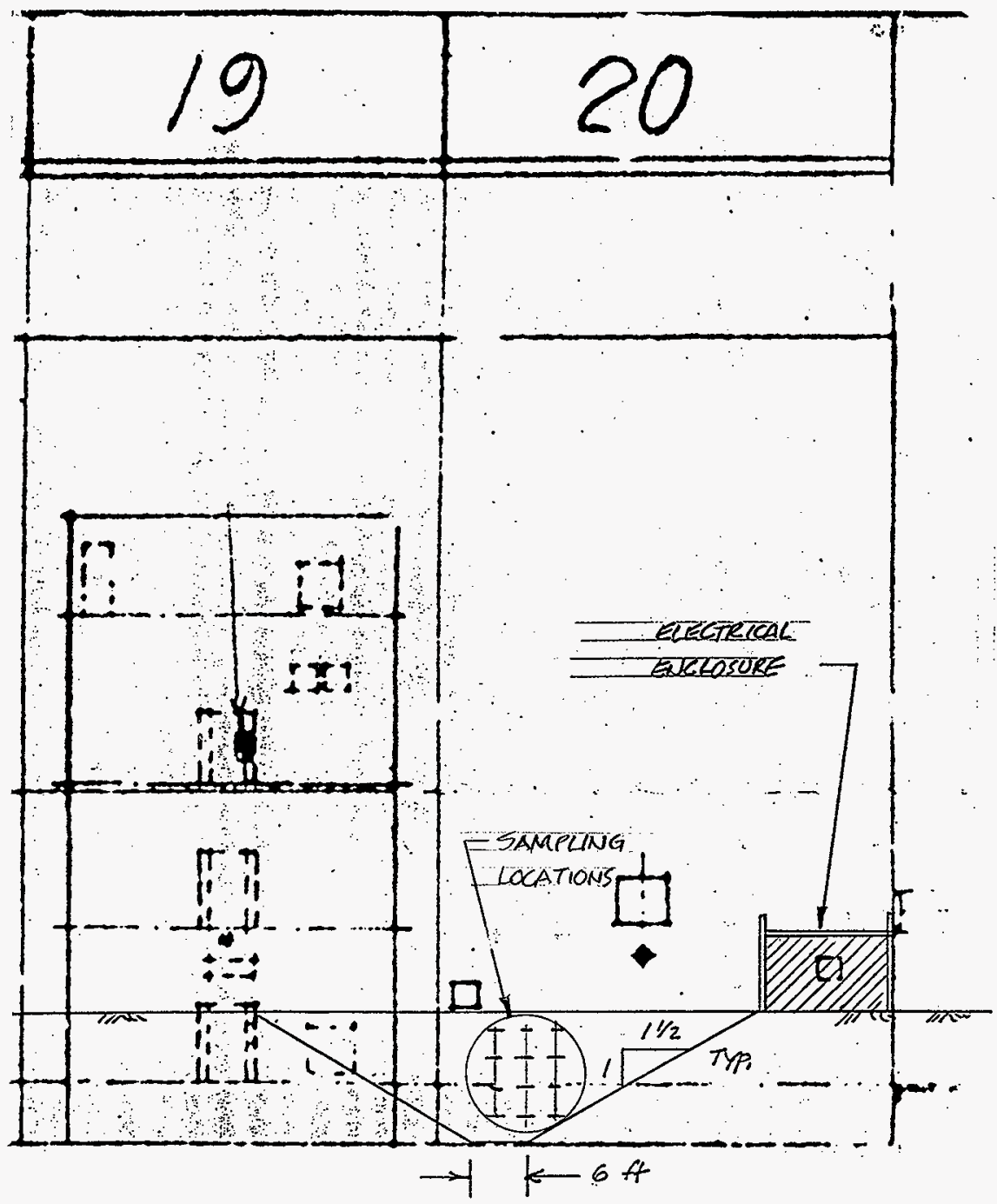

Figure 3-4. Below Grade Structural Sampling Locations. 
HNF-2580 Revision 0

\subsection{Worksheets for Structural Sampling}

Table 1 provides a summary of the NDE work and structural sampling that is planned to support verification of the reinforced concrete mechanical properties for Building 221-U. The table contains the following fields:

- Sample numbering for identification

- Sample locations

- Technical rationale

- Sample description

- Sampling and testing applicable standards

- Recording requirements

- Field support to be furnished by BHI

- Remarks 
Table 1. Technical Specification for Structural Sampling of 221-U Facility

\section{Table 1 Section A}

Above Grade Structural Sampling

Sidewall sampling: A total of 12 core samples and 12 rebar samples for strength testing; 12 core samples taken from 3 separate U-Plant segments, 1 rebar sample taken adjacent to each concrete core sample. 2 additional cores taken at segment 20 for petrography - see notes on Figure 3-1.

\begin{tabular}{|c|c|c|c|c|c|c|c|}
\hline $\begin{array}{l}\text { Sample } \\
\text { ID } \\
\text { number }\end{array}$ & Sample location & $\begin{array}{l}\text { Technical rationale } \\
\text { for testing }\end{array}$ & Sample description & $\begin{array}{l}\text { Sampling and testing } \\
\text { requirements }\end{array}$ & $\begin{array}{l}\text { Recording } \\
\text { requirements }\end{array}$ & $\begin{array}{l}\text { Required BHI } \\
\text { field support }\end{array}$ & Remarks \\
\hline $\begin{array}{l}20-\mathrm{C}- \\
002\end{array}$ & $\begin{array}{c}\text { See Figure } \\
3-1\end{array}$ & \multirow{3}{*}{$\begin{array}{l}\text { Concrete core } \\
\text { strength testing to } \\
\text { verify that in-situ } \\
\text { concrete meets } \\
\text { original design } \\
\text { strength }\end{array}$} & \multirow{3}{*}{$\begin{array}{l}6 \text { in diameter }+0, \\
-1 / 2 \text { in concrete } \\
\text { core, } \mathrm{L} / \mathrm{D} \geq 1.94, \\
\text { see note } 1 .\end{array}$} & \multirow{3}{*}{$\begin{array}{l}\text { ASTM C42-94 } \\
\text { ASTM C617-94 } \\
\text { ASTM C39-96 }\end{array}$} & \multirow{3}{*}{$\begin{array}{l}\text { a. ASTM C39-96 } \\
\text { and } \\
\text { ASTM C42-94 } \\
\text { b. } 8 \times 10 \text { in matte } \\
\text { B\&W photo each } \\
\text { core before and } \\
\text { after testing. }\end{array}$} & \multirow{3}{*}{ See note 2} & \\
\hline $\begin{array}{l}20-\mathrm{C}- \\
003\end{array}$ & $\begin{array}{c}\text { See Figure } \\
3-1\end{array}$ & & & & & & \\
\hline $\begin{array}{l}20-\mathrm{C}- \\
004\end{array}$ & $\begin{array}{c}\text { See Figure } \\
3-1\end{array}$ & & & & & & \\
\hline $\begin{array}{l}20-\mathrm{C}- \\
005\end{array}$ & $\begin{array}{c}\text { See Figure } \\
3-1\end{array}$ & $\begin{array}{l}\text { Concrete core } \\
\text { samples, control } \\
\text { samples for } \\
\text { petrography }\end{array}$ & $\begin{array}{l}6 \text { in diameter }+0 \text {, } \\
-1 / 2 \text { in concrete } \\
\text { core, } L / D \geq 1.94 \text {, } \\
\text { see note } 1 .\end{array}$ & ASTM C42-94 & None & See note 2 . & \\
\hline
\end{tabular}


Table 1 Section A (Continued)

Above Grade Structural Sampling

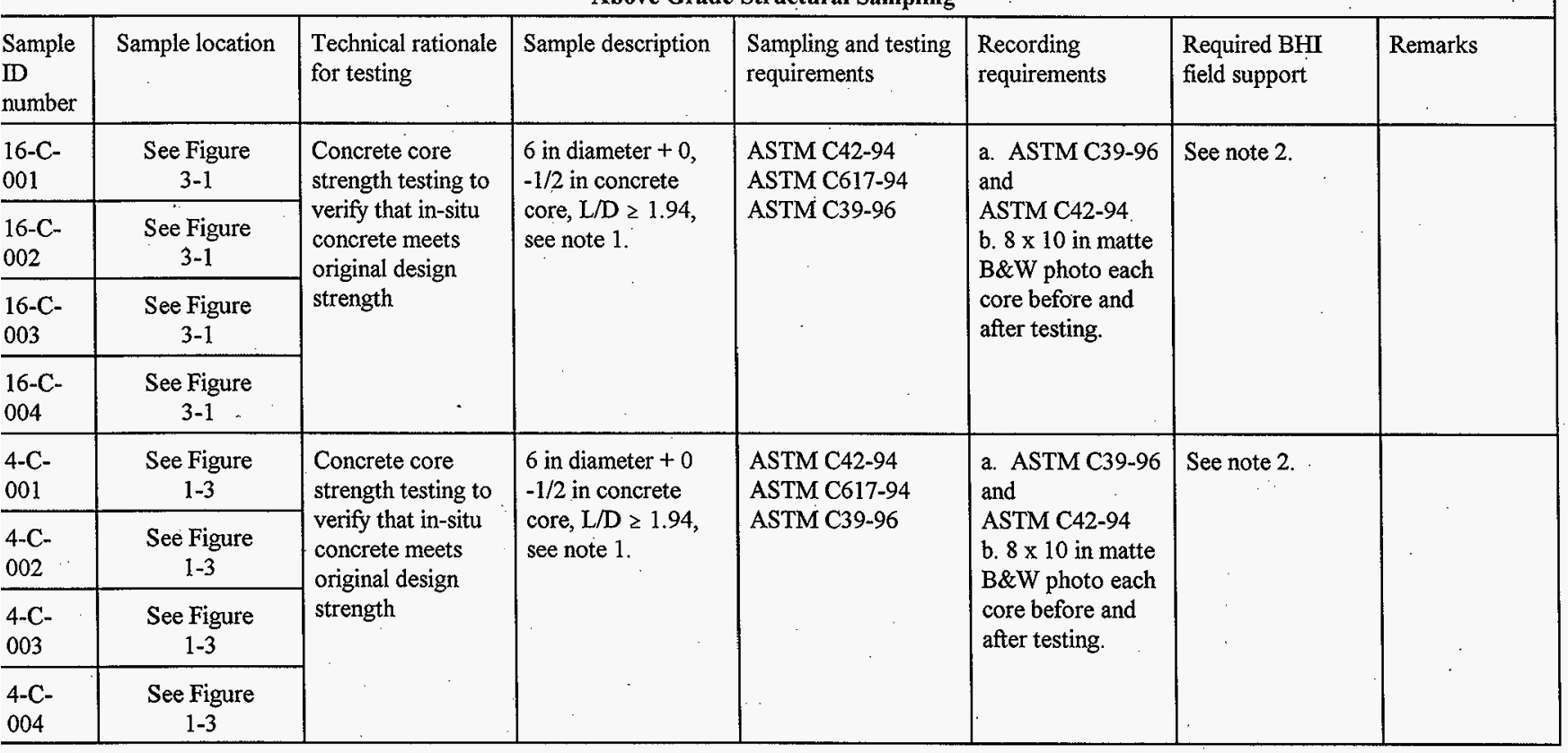




\section{Table 1 Section A (Continued)}

Above Grade Structural Sampling

\begin{tabular}{|c|c|c|c|c|c|c|c|}
\hline $\begin{array}{l}\text { Sample } \\
\text { ID } \\
\text { number }\end{array}$ & Sample location & $\begin{array}{l}\text { Technical rationale } \\
\text { for testing }\end{array}$ & Sample description & $\begin{array}{l}\text { Sampling and testing } \\
\text { requirements }\end{array}$ & $\begin{array}{l}\text { Recording } \\
\text { requirements }\end{array}$ & $\begin{array}{l}\text { Required BHI } \\
\text { field support }\end{array}$ & Remarks \\
\hline $\begin{array}{l}4-\mathrm{R}- \\
001\end{array}$ & $\begin{array}{c}\text { See Figure } \\
3-1\end{array}$ & \multirow{4}{*}{$\begin{array}{l}\text { Reinforcing steel } \\
\text { strength testing to } \\
\text { verify that in-situ } \\
\text { rebar meets } \\
\text { original design } \\
\text { strength }\end{array}$} & \multirow{4}{*}{$\begin{array}{l}26 \text { in long samples } \\
\text { of vertical rebar at } \\
\text { locations proximate } \\
\text { to the concrete } \\
\text { coring locations, } \\
\text { see note } 3 \text {. }\end{array}$} & \multirow{4}{*}{$\begin{array}{l}\text { ASTM A370-96 } \\
\text { including appendix } \\
\text { A.9 }\end{array}$} & \multirow{4}{*}{$\begin{array}{l}\text { a. ASTM A370- } \\
96 \\
\text { b. } 8 \times 10 \text { in matte } \\
\text { B\&W photo of } \\
\text { segment } 4 \text { rebar } \\
\text { samples before } \\
\text { and after testing. } \\
\text { c. Color photos } \\
\text { during rebar } \\
\text { excavation. }\end{array}$} & \multirow[t]{4}{*}{ See note 2 . } & \\
\hline $\begin{array}{l}4-\mathrm{R}- \\
002\end{array}$ & $\begin{array}{c}\text { See Figure } \\
3-1\end{array}$ & & & & & & \\
\hline $\begin{array}{l}\text { 4-R- } \\
003\end{array}$ & $\begin{array}{c}\text { See Figure } \\
3-1\end{array}$ & & & & & & \\
\hline $\begin{array}{l}4-\mathrm{R}- \\
004\end{array}$ & $\begin{array}{c}\text { See Figure } \\
3-1\end{array}$ & & & & & & \\
\hline \multicolumn{8}{|c|}{ Endwall sampling: A total of 9 core samples. Three sets of 3 core samples taken at locations shown in Figure 3-2. } \\
\hline $\begin{array}{l}1-\mathrm{C}- \\
001 \\
\end{array}$ & $\begin{array}{c}\text { See Figure } \\
3-2\end{array}$ & \multirow{4}{*}{$\begin{array}{l}\text { Concrete core } \\
\text { strength testing to } \\
\text { verify that in-situ } \\
\text { concrete meets } \\
\text { original design } \\
\text { strength }\end{array}$} & \multirow{4}{*}{$\begin{array}{l}6 \text { in diameter }+0, \\
-1 / 2 \text { in concrete } \\
\text { core, } L / D \geq 1.94, \\
\text { see note } 1 .\end{array}$} & \multirow{4}{*}{$\begin{array}{l}\text { ASTM C42-94 } \\
\text { ASTM C617-94 } \\
\text { ASTM C39-96 }\end{array}$} & \multirow{4}{*}{$\begin{array}{l}\text { a. ASTM C39-96 } \\
\text { and } \\
\text { ASTM C42-94 } \\
\text { b. } 8 \times 10 \text { in matte } \\
\text { B\&W photo each } \\
\text { core before and } \\
\text { after testing. }\end{array}$} & \multirow[t]{4}{*}{ See note 2} & \\
\hline $\begin{array}{l}1-\mathrm{C}- \\
002\end{array}$ & $\begin{array}{c}\text { See Figure } \\
3-2 \\
\end{array}$ & & & & & & \\
\hline $\begin{array}{l}1-\mathrm{C}- \\
003\end{array}$ & $\begin{array}{c}\text { See Figure } \\
3-2 \\
\end{array}$ & & & & & & \\
\hline $\begin{array}{l}1-\mathrm{C}- \\
004\end{array}$ & $\begin{array}{c}\text { See Figure } \\
3-2\end{array}$ & & & & & & \\
\hline
\end{tabular}


(CONTINUED)

\section{Table 1 Section B}

Below Grade Structural Sampling

Below grade sampling: A total of 12 core samples; 6 core samples to be used for strength testing, 6 core samples to be used for petrographic examination.

\begin{tabular}{l|c|}
\hline $\begin{array}{l}20-\mathrm{CU}- \\
001\end{array}$ & $\begin{array}{c}\text { See Figure } \\
3-4\end{array}$ \\
\hline $20-\mathrm{CU}-$ & $\begin{array}{c}\text { See Figure } \\
3-4\end{array}$ \\
003 & See Figure \\
$20-\mathrm{CU}-$ & $3-4$ \\
003 & S \\
\hline
\end{tabular}

\begin{tabular}{l|l}
$\begin{array}{l}\text { Petrographic } \\
\text { examinations to } \\
\text { evaluate aging } \\
\text { effects of the } \\
\text { environment on } \\
\text { the concrete } \\
\text { microstructure. }\end{array}$ & $\begin{array}{l}6 \text { in diameter }+0, \\
\text { core }, \mathrm{L} / \mathrm{D} \geq 1.94, \\
\text { see note } 1 .\end{array}$ \\
\hline
\end{tabular}

ASTM C856-95
as amended by
the statement of
work.

ASTM C42-94

ASTM C856-95
See note 2 .

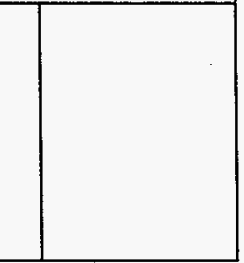


Table 1 Section B (Continued)

Below Grade Structural Sampling

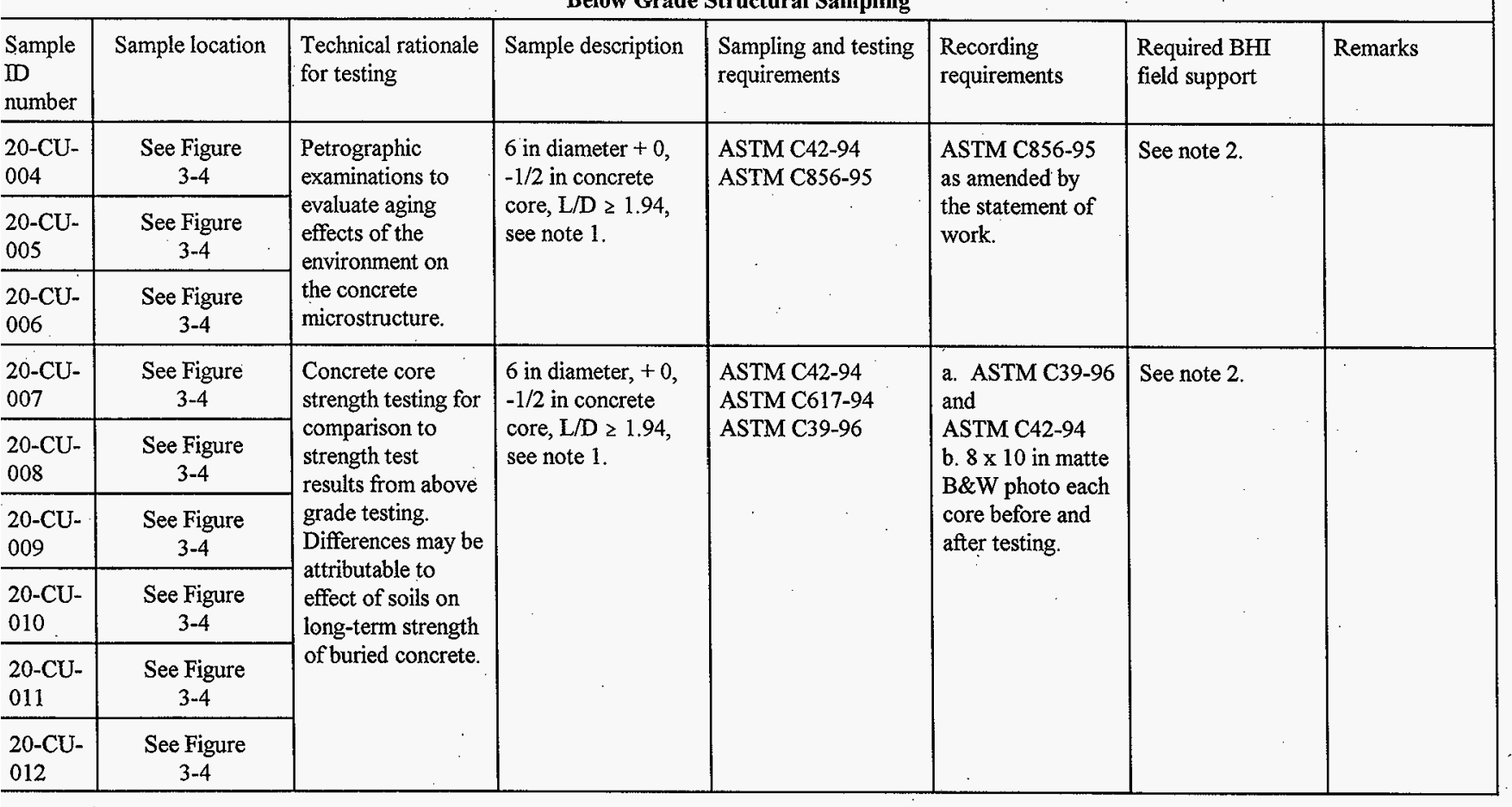




\section{Notes associated with Table 1:}

Note 1. Concrete core samples shall be between $6 \mathrm{in} .+0,-1 / 2$ in. diameter with an overall length of not less than 15 in from the outside vertical face of the wall. Cores shall be full length intact.. The coring subcontractor shall be responsible for storage of the structural samples, packaging and shipping to the test laboratory. The cores shall not be soaked prior to strength testing and shall be trimmed to the correct length and capped prior to unconfined compression testing.

Note 2. BHI shall provide the following support services to the subcontractor who performs the structural sampling and associated NDE rebar location activities:

- $\quad$ Escort services by facility operations personnel including HPT personnel to monitor coring activities in case contaminated concrete is encountered.

- Support utilities to include potable water for the diamond coring machine and concrete repair mix.

- Excavation support to provide access to the lower sidewall of the segment that is selected as the location for taking core samples that have been exposed long-term to Hanford soils. Backfill to restore grade after the structural samples have been acquired and the holes in the wall repaired.

- Procedure development, planning and scheduling for the above support activities, and permitting.

Note 3. Vertical rebar samples shall be separated from the sidewall with saw cuts before being excavated from the concrete. A trench shall be cut around each sample that is 6 in wide by 26 in long by 6 in deep (depth of saw cut). Trenches are needed to assist the excavation and provide an improved geometry for concrete repair. 
HNF-2580 Revision 0

\section{APPENDIX A \\ Petrographic Analysis Statement of Work}

\section{Introduction}

Concrete core samples will be taken from the 221-U building exterior walls above and below grade for petrographic examination. The samples will be prepared and examined in accordance with standard procedures to evaluate degradation mechanisms that will effect the long term durability and serviceability of the concrete.

\section{Work Scope/Deliverables}

Concrete core samples shall be provided to each of two test laboratories.

Four core samples will be furnished to Construction Technology Laboratories; one of these samples will be a control core taken from an above grade wall exposed to the atmosphere, and the other 3 core samples will be taken from a below grade wall where they have been exposed to the local soils and groundwater since 1944.

Two core samples will be furnished to Sandia Laboratories; one of these samples will be a control core taken from an above grade wall exposed to the atmosphere, and the other core sample will be taken from a below grade wall where it has been exposed to the local soils and groundwater since 1944 .

These cores will be used to prepare petrographic samples for examination in accordance with ASTM C856-95 and this statement of work.

\section{Purpose of the Petrographic Examinations}

The petrographic examinations are intended to establish the current condition of the in-situ concrete in the structure at the selected sample locations. Observations shall include a general description of the concrete.condition and observations on degradation mechanisms that are observed in the above and below grade samples. Degradation mechanisms showing significant differences between the above grade control specimen and the below grade sample cores shall be noted.

Degradation mechanisms for concrete can be separated into several categories.

Where possible, it is desired to separate the effects of short term construction related concrete degradation that occurred immediately after construction from long term effects.

Examples of short term effects include plastic shrinkage, incomplete hydration, and surface cracking that occurs immediately after placement during the curing period.

Long term effects include those effects due to material incompatibility such as alkali-silica reactions or 
other potential cement-aggregate reactions leading to degradation of concrete strength or integrity. A second type of long term effect is degradation caused by migration of chemicals or microscopic life forms into the concrete from the surrounding soil and groundwater system followed by reactions between these contaminants and the concrete materials. If examinations show variation in concrete degradation with depth into the concrete from the surface materials exposed to the underground soils, rough estimates of rate effects would be useful to allow extrapolation of likely future service life.

Core samples are being furnished to CTL for general petrograpic examination with the above purpose. The sample pair being furnished to Sandia Laboratories is for examination with respect to degradation mechanisms associated with aggressive chemicals in the groundwater vadose zones and potential degradation due to microbiotic activity such as anaerobic bacterial degradation of the cement matrix or cement aggregate bonds.

More detailed information on Hanford Site soil characteristics and the construction history for the heavy concrete pours will be furnished to the investigators at both laboratories prior to shipment of the cores for examination.

\section{Reporting:}

The laboratories standard letter report format should be used. A short discussion should be furnished describing sample selection and preparation and equipment used for the petrographic examinations. Photographic records should be made to support findings from the examination for record purposes. We generally publish in black and white; however, color photos and photomacrographs should be used where necessary to convey findings of the examinations. 